\title{
Determination of root mass ratios in alfalfa-grass mixtures using near infrared reflectance spectroscopy
}

\author{
M.D. RUMBAUGH, D.H. CLARK, AND B.M. PENDERY
}

\section{Abstract}

Hand separation of roots of 2 or more plants species from soll cores is a tedious and labor-intenoive task. Our objective was to determine whether near-infrared reflectance spectroscopy (NIRS) could be employed to estimate root biomass proportions in binary mixtures of alfalia (Medicago sativa $L$.) with each of 4 grasses. Grasses chosen for experimentation were crested wheatgrass (Agropyron cristatum L.), intermediate wheat grass [Thinopyrum intermedium (Host) Barkworth \& D.R. Dewey], an intergeneric hybrid [Elytrigia repens (L.) Nevski $\times$ Pseudoroegneria spicata (Pursh) Love], and Russian wildrye [Psathyrostachys juncea (Fisch.) Nevski]. In the first experiment, roots from single-species field plots were washed from soll cores, dried, ground, and mechanically mixed in preselected alfaira-grass ratios in which the percentage of grass varied from 0 to 100 . Equations to measure the proportion of alfalfa or grass were developed from near infrared reflectance data using 84 randomly selected samples. In the second experiment, the 5 plant species were grown in greenhouse pots in pure stands and in binary mixtures that included all combinations of the grasses. Root systems were separated while attached to the topgrowth, dried, and ground. Tiasues from single species treatments were mixed and calibration equations developed from these mixtures were used to estimate the proportion of alfalifa and the proportion of grass in samples. Samples contained either one type of root or a mixture of roots in proportions similar to those that occurred naturally in the pots. Coefficients of determination $\left(r^{2}\right)$ between the estimated and the actual root mass ratios ranged from 0.92 to 0.99 . Determination of the proportion of grass in the samples was more accurate and precise than determination of the proportion of alfalfa. After the appropriate calibration equations have been developed, NIRS is more efficient than hand separation for estimating alfalfa-grass root mass ratios. The utility of the techniques can be increased by developing equations that encompass more complex mixtures and a wider range of environmental circumstances.

Key Words: Agropyron cristatum L., crested wheatgrass, Elytrigia repens (L.) Nevski, intermediate wheat grass, Medicago sativa L., legume, NIRS, Psathyrostachys juncea (Fisch.) Nevski, Russian wildrye, Pseudoroegneria spicata (Pursh) Love, quackgrass, species composition, Thinopyrum intermedium (Host) Barkworth \& D.R. Dewey, wheatgrass

The relationships among plants in mixed species swards are of concern to ecologists, physiologists, agronomists, and range scientists. Many investigations involve the quantification of plant densities and top growth biomass ratios of the components of species mixtures. Similar measurements of root biomass often are not attempted because of the difficulty of correctly identifying and separating roots of different species.

Since the use of near infrared reflectance spectroscopy (NIRS) to measure forage quality was first described (Norris et al. 1976), the technique has been employed to determine the amounts and

\footnotetext{
Authors are research geneticist, research scientist, and range scientist, respectively, USDA-ARS Forage and Range Research Laboratory, Utah State Univ., Logan $84322-6300$

Cooperative investigations of the USDA-Agricultural Research Service and the Utah Agricultural Experiment Station. Approved as paper No. 3575.

Manuscript accepted 25 July 1988.
}

quality of several different types of forage (Clark et al. 1987, Minson et al. 1983, Shenk et al. 1979, Ward et al. 1982). NIRS was used to correctly determine the species composition of artificially created forage mixtures that contained as many as 4 species (Coleman et al. 1985). Botanical composition of tall fescue (Festuca arundinacea Schreb.)-white clover (Trifolium repens L.) pasture mixtures was predicted by NIRS with excellent precision and accuracy following proper selection of calibration samples, wavelengths, and data transformation (Petersen et al. 1987). Brink and Marten (1986) showed that NIRS could be used to analyze the total nonstructural carbohydrate content of alfalfa (Medicago sativa $L$.) roots; the technique was more convenient and accurate than conventional laboratory techniques. Our objective was to determine if NIRS could be used to quantify the root biomass ratios of alfalfa and 4 grass species when grown in binary mixtures.

\section{Materials and Methods}

\section{Experiment 1}

'NC-83-1'alfalfa (Kehr et al. 1975), 'Fairway' crested wheatgrass (Agropyron cristatum L), 'Oahe' intermediate wheatgrass [Thinopyrum intermedium (Host) Barkworth \& D.R. Dewey], 'RS-2' [Elytrigia repens (L.) Nevski $\times$ Pseudoroegneria spicata (Pursh) Love], and 'Vinall' Russian wildrye [Psathyrostachys juncea (Fisch.) Nevski] plants were started in the greenhouse and transplanted to the field near Logan, Utah, in May 1983. All plants were spaced $0.5 \mathrm{~m}$ apart in a rectangular grid pattern. Details of the nursery plan were described by Rumbaugh and Pendery (1986). The experimental field is at an elevation of $1,369 \mathrm{~m}$ and receives an average of $440 \mathrm{~mm}$ precipitation annually. The soil is a coarse, silty caronatic, mesic, Typic Haplozeroll.

Soil blocks $25 \mathrm{~cm} \times 20 \mathrm{~cm}$, extending $25-\mathrm{cm}$ deep, and centered between 2 plants of the same population were extracted in July 1986. Two hundred samples were obtained for each of the 5 plant species. The samples were stored in plastic bags at $4^{\circ} \mathrm{C}$ until processed. Soil samples were soaked in water for 1 hour and the roots were extracted by careful washing with a fine, pressurized spray of cold water over a fine screen. Detritus was removed with a forceps. Root samples for each species were bulked, dried in a forced-air oven at $40^{\circ} \mathrm{C}$, and ground with a UDY mill to pass through a I-mm screen.

Samples for NIRS analysis were prepared from pure root tissue. Mixtures of legume-grass root tissue were created by mixing known weights of alfalfa and grass. This was performed for all legume-grass combinations and the mixtures ranged from $100 \%$ alfalfa to $100 \%$ grass in increments of $5 \%$. With these combinations, a total of 100 samples (25 mixtures for each legume-grass species combination) were generated. Of the 100 samples, 84 were randomly selected for calibration (equation development) and 16 were used to test the equation. Variables used for equation development and testing were percentage alfalfa and grass root mass.

Equations were developed by collecting the spectra on each sample with a scanning monochromator Pacific Scientific model $6350^{1}$ coupled to a DEC ${ }^{1}$ PDP $11 / 23$ computer. Spectra were

\footnotetext{
Mention of a trademark or proprietary product does not constitute a guarantee or warranty of the product by the USDA or the Utah Agricultural Experiment Station and does not imply its approval to the exclusion of the other products that may also be suitable.
} 
collected from $1,100-2,500 \mathrm{~nm}$ at every $2 \mathrm{~nm}$ for a total of 700 data points per sample. Percent root mass was entered into the computer for each sample and multiple linear regression equations were developed by regressing the spectral and root mass data. Equations were selected based on lowest standard error of calibration (SEC), highest $R^{2}$, and all wavelengths in the equation having an $\mathrm{F}$ value $>$ 10.0 (Abrams et al. 1987). Selected equations were tested on the remaining 16 samples and success was measured by a low standard error of performance (SEP), bias, and high $r^{2}$.

\section{Experiment 2}

The 5 species used in experiment 1 were established in $15-\mathrm{cm}$ diameter pots in the greenhouse in January 1987. The 15 treatments consisted of 4 plants of 1 species or 2 plants of each 2 species in binary mixtures. Alfalfa seedlings were treated with a commercial inoculum as they were transplanted into the pots. The rooting medium was a sandy-loam soil enriched with a nitrogen-free fertilizer. The experimental design was a randomized complete block with 25 replications of the 15 treatments. Alfalfa plants were at the initial-bloom stage and the grasses vegetative when harvested during the last week of March 1987. Roots from the binary mixtures were carefully separated by species while still attached to the topgrowth. Roots from plants of a single species were bulked within each treatment, dried in a forced-air oven at $34^{\circ} \mathrm{C}$, and ground as previously described.

Only root tissues from pots containing a single species were used to develop the NIRS equations. Ground roots from each of the 5 species were used alone or were blended in binary mixtures in $25 \%$ increments to create samples ranging from 0 to $100 \%$ composition for each species. These 35 samples were used to develop 2 multiple linear regression equations. The first equation quantified the proportion of alfalfa tissue in the samples and the second the proportion of grass. Not enough grass roots were available to develop equations to estimate individual grass populations. Fifteen test samples were formulated. Five consisted of roots from the single species treatments. Ten other test samples were created by reconstituting the binary-mixtures, using root tissues from the same binary mixture treatments, in proportions identical to the averages of those that occurred naturally in the pots.

\section{Results}

\section{Experiment 1}

In many pastures investigations, it is necessary only to distinguish the root mass of one species, such as alfalfa, from the roots of another crop species category, such as grass. Results involving artificial mixtures show that NIRS could be used to distinguish between root masses with a degree of precision and accuracy that would be appropriate for most experimentation (Table 1). Coeffi-

Table 1. Calibration and analysis statistics for NIRS measurement of the percentages of alfalifa and grass roots in artifichal mixtures. Plants used in Experiment 1 were grown in the field and those used in Experiment 2 were grown in the greenhouse.

\begin{tabular}{|c|c|c|c|c|c|c|c|}
\hline \multirow[b]{2}{*}{ Crop } & \multicolumn{4}{|c|}{ Calibration } & \multicolumn{3}{|c|}{ Analysis } \\
\hline & $\begin{array}{c}\text { Mean } \\
(\%)\end{array}$ & Terms & $\mathbf{R}^{2}$ & $\begin{array}{c}\text { SEC } \\
\text { (\%) }\end{array}$ & $\begin{array}{l}\text { Bias } \\
(\%)\end{array}$ & $\mathbf{r}^{2}$ & $\begin{array}{c}\text { SEP } \\
(\%)\end{array}$ \\
\hline $\begin{array}{l}\text { Experiment 1: } \\
\text { Alfalfa } \\
\text { Grass }\end{array}$ & $\begin{array}{l}50.1 \\
49.9\end{array}$ & $\begin{array}{l}5 \\
5\end{array}$ & $\begin{array}{l}0.99 \\
0.99\end{array}$ & $\begin{array}{l}1.48 \\
1.48\end{array}$ & $\begin{array}{r}-1.25 \\
1.25\end{array}$ & $\begin{array}{l}0.99 \\
0.99\end{array}$ & $\begin{array}{l}2.15 \\
2.15\end{array}$ \\
\hline $\begin{array}{l}\text { Experiment 2: } \\
\text { Alfalfa } \\
\text { Grass }\end{array}$ & $\begin{array}{l}53.8 \\
84.1\end{array}$ & $\begin{array}{l}2 \\
2\end{array}$ & $\begin{array}{l}0.99 \\
0.99\end{array}$ & $\begin{array}{l}1.82 \\
1.73\end{array}$ & $\begin{array}{l}-4.14 \\
-2.14\end{array}$ & $\begin{array}{l}0.95 \\
0.98\end{array}$ & $\begin{array}{l}6.38 \\
4.52\end{array}$ \\
\hline
\end{tabular}

SEC = Standard error of calibration.

SEP $=$ Standard error of performance.

Terms = number of wavelengths in equation

Bias = NIRS mean minus the actual mean. cients of variation [CV $=(\mathrm{SEP} /$ mean of the validation data set $) \times 100]$ were $2.5 \%$ for alfalfa and $4.3 \%$ for grass. Both values were as low as comparable estimates for forage biomass usually found in most agronomic and ecological studies. Discrepancies between the actual and determined means (bias) were $-3.7 \%$ and $1.9 \%$ of the actual means of the alfalfa and grass samples, respectively.

Estimated root biomass ratios for alfalfa and the 5 individual grasses were less accurate and precise than simply distinguishing between alfalfa and any grass species. SEC were less than $2 \%$ and the corresponding $R^{2}$ values exceeded 0.99 (Table 2 ). When the

Table 2. The proportions of roots of field-grown alfalin and 4 grasses in artificial legume-grass mixtures (Experiment 1): a comparison of actual percentages versus those determined by NIRS.

\begin{tabular}{|c|c|c|c|c|c|c|c|}
\hline \multirow[b]{2}{*}{ Crop } & \multicolumn{2}{|c|}{ Actual $(n=50)$} & \multicolumn{5}{|c|}{ Determined $(n=50)$} \\
\hline & Mean & SD & Mean & $\begin{array}{l}\text { SD } \\
-(\%)\end{array}$ & Bias & $\mathbf{r}^{2}$ & $\begin{array}{l}\text { SEP } \\
(\%)\end{array}$ \\
\hline $\begin{array}{l}\text { Alfalfa } \\
\text { Fairway } \\
\text { Oahe } \\
\text { RS-2 } \\
\text { Vinall }\end{array}$ & \begin{tabular}{r|}
51.1 \\
12.4 \\
14.4 \\
6.2 \\
15.8
\end{tabular} & $\begin{array}{l}29.7 \\
25.9 \\
26.4 \\
18.5 \\
30.6\end{array}$ & $\begin{array}{r}50.4 \\
10.1 \\
16.1 \\
8.5 \\
16.2\end{array}$ & $\begin{array}{l}29.2 \\
25.1 \\
25.7 \\
20.2 \\
29.9\end{array}$ & $\begin{array}{r}-0.7 \\
-2.3 \\
1.7 \\
2.3 \\
0.4\end{array}$ & $\begin{array}{l}0.995 \\
0.965 \\
0.964 \\
0.920 \\
0.962\end{array}$ & $\begin{array}{l}2.09 \\
5.34 \\
5.25 \\
6.14 \\
5.96\end{array}$ \\
\hline
\end{tabular}

SD = Standard deviation.

SEP = Standard error of performance.

Bias = NIRS mean minus the actual mean.

equations were tested on 16 other samples. SEP values were approximately $5 \%$ and produced high coefficients of determination. However, coefficients of variation ranged from $36.5 \%$ when estimating Oahe intermediate wheatgrass to $99.0 \%$ for the RS-2 species hybrid. The bias in the estimated proportion of alfalfa root mass was $-1.4 \%$ of the actual mean. Analogous values for the 4 grasses ranged from $2.5 \%$ (Vinall Russian wildrye) to $37.1 \%$ (RS-2 hybrid). However, in no case was the $r^{2}$ less than 0.92 .

\section{Experiment 2}

NIRS successfully discriminated between greenhouse-grown alfalfa root tissue and grass root tissue although the estimates of the proportions of the $\mathbf{2}$ species were neither as accurate nor as precise as in the field study (Table 1). The standard errors of analysis were 3-fold greater than in Experiment 1 and the biases were $-6.0 \%$ and $-2.6 \%$ of the actual means of the alfalfa and grass samples, respectively. However, the coefficients of determination ( 0.95 or above) indicated very acceptable levels of precision.

Determination of the proportion of alfalfa in a sample containing only alfalfa was very accurate as indicated by a bias amounting to only $0.3 \%$ (Table 3 ). When NIRS was used to determine the proportion of grass in a sample that contained only alfalfa, the resulting estimate was negative. When NIRS was used to determine the amount of alfalfa in samples that contained both alfalfa and grass root tissues, biases ranged from 5.6 to $-19.9 \%$ of the actual alfalfa means and averaged $-8.9 \%$. When the same samples were used to estimate the amounts of the grasses, biases ranged from -4.6 to $-28.4 \%$ of the actual grass means and the average bias was $-13.8 \%$. When 2 grasses were included in the samples, biases ranged from $-9.3 \%$ for crested and intermediate wheatgrasses to $4.8 \%$ for the crested wheatgrass and Russian wildrye mixture. The mean absolute bias of binary grass mixtures was $4.4 \%$. The mean absolute bias for all NIRS determinations of the proportion of alfalfa was $6.1 \%$ which was the equivalent of $26.5 \%$ of the actual mean proportion of alfalfa in the 15 samples. Similarly, the mean absolute bias for grass was $3.7 \%$ which was $5.0 \%$ of the mean proportion of grass. Thus, NIRS determinations of the proportion of grass were more accurate than those of alfalfa in Experiment 2.

\section{Discussion}

Hand separation of roots of $\mathbf{2}$ or more species is very tedious, 
Table 3. Actual and determined proportions of alfalif and grass in binary root tiacue samples (Experiment 2).

\begin{tabular}{|c|c|c|c|c|c|c|c|c|}
\hline \multicolumn{5}{|c|}{ Actual proportions (\%) } & \multicolumn{4}{|c|}{ Analyzed proportions (\%) } \\
\hline \multirow[b]{2}{*}{ Alfalfa } & \multirow{2}{*}{\multicolumn{2}{|c|}{ Crested Intermedia }} & \multirow[b]{2}{*}{ e RS-2 } & \multirow[b]{2}{*}{ Vinall } & \multicolumn{2}{|c|}{ Alfalfa } & \multicolumn{2}{|c|}{ Grass } \\
\hline & & & & & Mean & Bias & Mean & Bias \\
\hline 100.0 & & & & & 100.3 & 0.3 & -4.3 & -4.3 \\
\hline 0.0 & 100.0 & & & & 9.9 & 9.9 & 101.9 & 1.9 \\
\hline 0.0 & & 100.0 & & & 7.0 & 7.0 & 100.6 & 0.6 \\
\hline 0.0 & & & 100.0 & & 6.9 & 6.9 & 97.2 & -2.8 \\
\hline 0.0 & & & & 100.0 & 7.1 & 7.1 & 101.4 & 1.4 \\
\hline 78.9 & 21.1 & & & & 71.7 & -7.2 & 15.1 & -6.0 \\
\hline 40.7 & & 59.3 & & & 32.6 & -8.1 & 56.6 & -2.7 \\
\hline 53.8 & & & 46.2 & & 56.9 & 3.0 & 38.7 & -7.5 \\
\hline 71.3 & & & & 28.7 & 62.5 & -8.8 & 26.8 & -1.8 \\
\hline 0.0 & 61.4 & 38.6 & & & 8.2 & 8.2 & 90.7 & -9.3 \\
\hline 0.0 & 42.2 & & 57.8 & & 10.7 & 10.7 & 93.1 & -6.9 \\
\hline 0.0 & 75.0 & & & 25.0 & 1.2 & 1.2 & 104.8 & 4.8 \\
\hline 0.0 & & 67.9 & 32.1 & & 0.3 & 0.3 & 101.2 & 1.2 \\
\hline 0.0 & & 88.5 & & 11.5 & 6.2 & 6.2 & 100.6 & 0.6 \\
\hline 0.0 & & & 67.8 & 32.2 & 6.7 & 6.7 & 96.6 & -3.4 \\
\hline
\end{tabular}

Bias = NIRS mean minus the actual mean.

labor intensive, and subject to major identification errors if the roots are not attached to the aboveground growth. For these reasons, the numbers of samples taken in root-core studies often are more limited than desired. Less time and labor consuming techniques, such as the use of NIRS to measure the proportions of legume and grass roots, may facilitate more extensive sampling of research plots in certain types of pasture and range management experiments. While the root mass still must be washed free of soil, dried, and ground prior to NIRS determination, hand separation of the species in the sample would not be necessary once appropriate calibration equations have been developed.

Our procedures and results were analogous to those of Coleman et al. (1985) and Petersen et al. (1987) who used NIRS to measure the species composition of forage mixtures. The calibration data using root tissues were subject to the same composition, machine, sampling, and methodology errors that affected forage tissues. Similarly $r^{2}$ values in these previous studies were slightly higher when estimating the proportion of alfalfa tissue than when estimating the proportion of grass tissue in mixed species samples.

Our study involved only samples that contained no more than 2 species whereas the mixtures studied by Coleman et al. (1985) contained as many as 4 species. Seeded pastures often contain only 2 species but the NIRS technique would have application to a broader range of experimentation if root calibration equations were developed for specific components of more complex mixtures. The components of such mixtures would have to differ sufficiently so that NIRS procedures could measure differences in molecular motion of the chemical bonds associated with their respective organic compounds. Additional research also will be required to determine whether it is feasible to use a common equation to measure the proportions of root biomass in samples collected from different soils with varying fertility levels and precipitation regimes. Data from the 2 experiments described lead us to conclude that NIRS technology can be used to develop procedures to estimate the proportions of root biomass of different plant species.

\section{Literature Cited}

Abrams, S.M., J.S. Shenk, M.O. Westerhaus, and F.E. Barton Il. 1987. Determination of forage quality by near infrared reflectance spectroscopy: efficacy of broad-based calibration equations. J. Dairy Sci. 70:806-813

Brink, G.E., and G.C. Marten. 1986. Analysis of alfalfa root carbohydrate concentration by near infrared reflectance spectroscopy. Crop Sci. 26:159-161.

Clark, D.H., H.F. Mayland, and R.C. Lamb. 1987. Mineral analysis of forages with near infrared reflectance spectroscopy. Agron. J. 79:485-490.

Coleman, S.W., F.E. Barton II, and R.D. Meyer. 1985. The use of nearinfrared reflectance spectroscopy to predict species composition of forage mixtures. Crop Sci. 25:834-837.

Kehr, W.R., D.K. Barnes, E.L. Sorensen, W.H. Skrdle, C.H. Hanson, D.A. Mller, T.E. Thompson, I.T. Carleon, L.J. Elling, R.L. Taylor, M.D. Rumbaugh, E.T. Bingham, D.E. Brown, and M.K. Miller. 1975. Registration of alfalfa germplasm pools NC-83-1 and NC-83-2. Crop Sci. 15:604-605.

Minson, D.J., K.L. Butler, N. Grummitt, and D.P. Law. 1983. Bias when predicting crude protein, dry matter digestibility and voluntary intake of tropical grasses by near-infrared reflectance. Anim. Feed Sci. Tech. 9:221-237.

Norris, K.H., R.F. Barnes, J.E. Moore, and J.S. Shenk. 1976. Predicting forage quality by infrared reflectance spectroscopy. J. Anim. Sci. 43:889-897.

Petersen, J.C., F.E. Barton, II, W.R. Windham, and C.S. Hoveland. 1987. Botanical composition definition of tall fescue-white clover mixtures by near infrared reflectance spectroscopy. Crop Sci. 27:1077-1080.

Rumbauch, M.D., and B.M. Pendery. 1986. Interspecific relations and the breeding of pasture plants for semiarid regions. p. 285-290. In: T.A. Williams and G.S. Wratt (ed.). Plant Breeding Symp., DSIR, 1986. Agron. Soc. New Zealand Spec. Pub. 5. Christchurch, New Zealand.

Shenk, J.E., M.O. Weaterhaus, and M.R. Hoover. 1979. Analysis of forages by infrared reflectance. J. Dairy Sci. 62:807-812.

Ward, R.G., G.S. Smith, J.D. Wallace, N.S. Urquhart, and J.S. Shenk. 1982. Estimates of intake and quality of grazed range forage by near infrared reflectance spectroscopy. J. Anim. Sci. 54:399-402. 